European journal of American studies

$10-2$ | 2015

Summer 2015, including Special Issue: (Re)visioning

America in the Graphic Novel

\title{
Rudy Kelly's Eyes: Chris Hedges and Joe Sacco's Days of Destruction, Days of Revolt
}

\section{Øyvind Vågnes}

\section{(2) OpenEdition \\ Journals}

Electronic version

URL: https://journals.openedition.org/ejas/10998

DOI: $10.4000 /$ ejas. 10998

ISSN: 1991-9336

Publisher

European Association for American Studies

Electronic reference

Øyvind Vågnes, "Rudy Kelly's Eyes: Chris Hedges and Joe Sacco's Days of Destruction, Days of Revolt", European journal of American studies [Online], 10-2 | 2015, document 8, Online since 14 August 2015, connection on 08 July 2021. URL: http://journals.openedition.org/ejas/10998 ; DOI: https://doi.org/ 10.4000/ejas. 10998

This text was automatically generated on 8 July 2021.

Creative Commons License 


\title{
Rudy Kelly's Eyes: Chris Hedges and Joe Sacco's Days of Destruction, Days of Revolt
}

\author{
Øyvind Vågnes
}

1 A few pages into "Days of Devastation," the third chapter of Chris Hedges and Joe Sacco's Days of Destruction, Days of Revolt, the authors arrive in the old coal-mining town of Gary, West Virginia, where they are introduced to a ninety-year-old man named Rudy Kelly, "a large robust man who worked as a miner for forty years and has spend the last couple of decades fighting off black lung disease" (Hedges and Sacco 133). The reader will already know from reading the preceding pages that Gary is located in a bend of the Tug Fork of the Big Sandy River, and that it was built in the early twentieth century by U.S. Steel, "the country's first billion-dollar corporation" (132). S/he will also know the depressingly familiar story of the town's turn for the worse: in 1986 U.S. Steel closed their plant there and twelve hundred workers lost their job from one day to the next, after which the community "fell into terminal decay" (132). This foray into the history of a town prepares the reader for what follows: over nine full pages of graphic narrative Sacco takes the time to delve into Rudy Kelly's life story in great detail, in an attempt to show the reader how it was marked by the rise and fall of his hometown. From his early years of carrying ice to houses that did not have water when he was a child, through his decades of working in the coal mines from age seventeen and onwards, Kelly's life has been one of hard work in service to family, community, and to the society at large.

2 The stories of Gary, other towns like it in West Virginia, and of Kelly serve as a background for the form of unflinchingly opinionated political analysis that follows, for which Hedges is known. This narrative strategy is typical of Days of Destruction, Days of Revolt, where information-driven journalism backed by references in endnotes allows macro and micro histories to blend and serve 
as background for a series of encounters with human beings that are all but bereft of their dignity. The book describes the predicament of the rapidly growing underclass in the States, victims of corporate capitalism in what Hedges refers to as "sacrifice zones," areas that have been offered up for exploitation in the name of profit (xi). Throughout its five chapters the reader is introduced to despaired people living on the Pine Ridge Lakota reservation in South Dakota; the homeless of Camden, N.J.; migrant workers assigned to pick tomatoes in worker camps in Florida; and individuals suffering from and resisting mountain-top removal by coal companies in West Virginia, or individuals who have worked for these companies through their lives only to find themselves unemployed in the eighties-like Rudy Kelly. In 2011, the year before Days of Destruction, Days of Revolt was published, the Census Bureau reported that the number of Americans living below the poverty line, 46.2 million people, was the highest in the 52 years they had existed (Harcourt 37). The book is a response to this situation, and thus belongs solidly in the tradition of social reportage, alongside classics such as James Agee and Walker Evans's Let Us Now Praise Famous Men and more recent contributions such as William T. Vollmann's 2007 collection Poor People. Although itinscribes itself into such a tradition with a welcome sense of energy, passion and ethical integrity, however, the book can also be said to represent a departure from it in significant ways. This article will focus on the verbal-visual strategies which lend this doubleness to Days of Destruction, Days of Revolt, and which define its innovation and originality, and ultimately make it a narrative that resists any conventional generic description. Since the book is extensive in its approach and covers a lot of ground I will pay particular attention to the depiction of Kelly's story and the chapter in which it appears.

3 Days of Destruction, Days of Revolt is marked by a tone that distinguishes it from its predecessors; it is markedly less self-reflexive and self-critical. As is often the case with a publication of its kind, Vollmann's Poor People opens with an introduction in which its author rhetorically both places it in a tradition and at the same time proposes new directions for that very tradition. Thus Poor People, described by Michele Hardesty as "a globalized, critical rewriting" of Let Us Now Praise Famous Men (Hardesty 100), offers a few reflections on that very book in its early pages. As many readers will know Let Us Now Praise Famous Men was first published in 1941 and grew out of an assignment in 1936 to produce a magazine article on the conditions sharecropper families in the South lived during the "Dust Bowl." Vollmann offers an ambivalent characterization of Agee and Evans's project in his introduction where he refers to it as a "masterpiece" (Vollmann: xi), but also as "an elitist expression of egalitarian longings" characterized by a "tragic tension between its goal and its means"-a tension, Vollmann writes, which "contributes to its greatness" (xii). To Vollmann the book's repeated attempts to express its own insufficiency-or Agee's "self-loathing" tone (xiii), as he describes it-is an expression of guilt (xi). On the contrary, his own emotion, writes Vollmann, is not guilt, but rather "gratitude" (xi). "I do not wish to experience poverty," Vollmann writes, "for that would require fear and hopelessness. Therefore, I can glimpse it only from the outside. This essay is not written for poor people, or for anyone in 
particular. All that I dare to do is to note several similarities and differences which I believe pertain to the experience of being poor" (xiv). Having spent only a few days with each of his subjects Vollmann thinks it "fatuous" to hope to "make a difference" (xv). Even as he distances himself from of Agee and Evans, then, Vollmann's own tone is characterized by what Hardesty describes as an obsession with failure (124).

4 Days of Destruction, Days of Revolt does not share this tendency to selfquestioning; neither does it gesture implicitly or explicitly towards an inscription of itself into any canon. In fact, the authors do not allow themselves to pause too much to reflect on the brevity of their encounters with the people they meet, concentrating more on a combination of extensive research and informed journalism than self-reflexivity. Sacco is known for including his own person in the form of a carefully constructed persona in almost all of his work, often in order to draw attention to the subjective quality of his stories, to his translation of oral testimony into drawn images. This persona is entirely absent from the pages of Days of Destruction, Days of Revolt. Hedges and Sacco's book is marked byits commitment to bringing the story across with efficiency and depth. When it in its concluding pages culminates in a report from Zucotti Park in New York City, where Sacco provides one of his great drawings of the bustling activity going on, sprawling with detail (Hedges and Sacco 258-259), and where the crowds lead Hedges to conclude that the Occupy movements are "the physical embodiment of hope," the book is infused by a spirit of rebellion, by a hardened insistence that individuals can contribute in making a difference.

5 What makes Days of Destruction, Days of Revolt the most radical departure from the tradition it is destined to be inscribed into, however, is of course its combined use of drawings in the form of illustrations and comics reportage in the place of photography. Although Sacco has done work as an illustrator before, notably the brief graphic narratives in Priscilla Murolo and A. B. Chitty's From the Folks Who Brought You the Weekend: A Short, Illustrated History of Labor in the United States, his contributions to Days of Destruction, Days of Revolt is more as a co-author and collaborator than as an illustrator. His portraits and landscapes scatter the pages, and in each chapter of the book there is one more or less autonomous graphic narrative which tells an individual's story at some length. These stories tend to go back in time in their visualization of events of the past. Instead of debating the implications of this use of drawn images where readers would be more accustomed to photography, the book goes about its business with an implied confidence in its own method, leaving the generic description up to others. One result of this is that Hedges and Sacco do not need to concern themselves with a specific, pessimistic tradition of thinking about social photography, more precisely the orientation Susie Linfield refers to in her 2010 book The Cruel Radiance as the "indictment" of photography, launched by Susan Sontag, Roland Barthes, and John Berger, and re-articulated more recently by what Linfield refers to as "the postmoderns," among them Allan Sekula and Abigail Solomon-Godeau. To Linfield all these critics tend to see photography as "a powerful, duplicitous force to defang, rather than an 
experience to embrace and enlarge" (Linfield 5). Although "[t]he depiction of powerless, vulnerable people is a fraught enterprise that can easily veer into condescension," Linfield observes, "from [the postmodern] critics it evoked a tsunami of too-easy scorn," and, she writes, led them into an obsession with victimization (12).

6 As Roger Hallas observes, photojournalism has gone through substantial transformations with the advent of digital technology, as news publications increasingly tend to outsource their photographic needs to commercial photo agencies, and Getty Images and Corbis represent a corporate "duopoly"; there are immense digital archives, and amateur photographers play an increasing role in news production (99). Furthermore photojournalism has been motivated by an intention to "improve the world," Hallas argues in reference to an article by Liz Jobey, but has grown frustrated by "the growing incursion of celebrity reporting in even the most serious-minded of news institutions" (100). This has led several prolific photojournalists into a form of "visual activism" as they feel that taking assignments from nongovernmental organizations (NGOs) leaves them more autonomy (100-101). Doing work for NGOs appeals to photojournalists "who are questioning both the specific visual styles of classical photojournalism and its abiding assumptions about the profession's political function and ethical values" (111).

7 Undoubtedly such developments form a background for the appearance of a book such as Days of Destruction, Days of Revolt, which obviously represents an alternative to photojournalism. But the book raises a new set of questions that need to be articulated from a different perspective than those of social photography: What constitutes the authenticity and ethical integrity of its use of the drawn documentary image in its pages? As Paul Ward suggests when writing about non-fiction animation film, a tradition of scholarly writing on documentary film builds on the basic distinction between "non-fiction"-that is footage, or "the simple recording of an event"-and John Grierson's definition of documentary as a "creative treatment" of this material (Ward 7-8). The consequence is that animated documentary, a markedly subjective mode peculiarly located between reality and invention, is too quickly judged for a lack of realism because it lacks an indexical correspondence to a pro-filmic actuality (84-86). But animated films, Ward argues, can in fact offer us "an intensified route into understanding the real social world" precisely because of its defining dialectic, namely that it concerns something that is real and yet entirely constructed, "with nothing of the indexical correspondence that we have become so accustomed to" (91). Although Ward's reflections concern animation film it is not difficult to see how they are relevant to the consideration of any form of non-photographic documentarism. This urges a rethinking of the very nature and place of indexicality in our considerations of the drawn documentary image. Comics scholar Hillary Chute offers significant insights into how we can begin to address such a notion of indexicality. The hand-drawn image, argues Chute, "registers the subjective bodily mark on the page" so that "its marks are an index of the body," and it is in fact this very "handwritteness" of comics which constitutes its indexicality, which makes the form "invested in the auratic but an auratic that is divorced from fixed notions 
of the authentic" (112). To Charles Hatfield this paradox represents what he refers to as a form of "ironic authentication": "through the admission of artifice," he writes, the comics artist is "graphically asserting truthfulness" (130-131). In other words, we need to look at Sacco's portrait of Rudy Kelly and think of it as a drawing, not as something resembling a photographic record, even if Sacco has used his camera in doing research for the depiction (Vågnes, "Inside the Story" 210; Spurgeon); we need to think of it as Sacco's rendering by hand of an encounter with Kelly and come to terms with how its authenticity is marked by what Chute refers to as its "handwritteness." As Rebecca Scherr points out, "the resonant, emotional quality of many graphic memoirs depends on the reader's apprehension of the hands of the author, that is, the trace of the author's presence in every curve and line of the text" (22).

8 Attention needs to be paid to how this trace of authorial presence infuses the drawn documentary image with a particular, subjective quality. "Technique has a bad name; it can seem soulless," writes Richard Sennett in The Craftsman, but continues: "That's not how people whose hands become highly trained view technique. For them, technique will be intimately linked to expression" (149). These remarks come in a chapter devoted to "the hand" and its "repertoire of learned gestures" (178). According to Sennett craftsmanship has become undervalued in contemporary society, a development that came with the advent of the industrial era. But The Craftsman offers something else and much more complex than a nostalgic lamentation on a bygone past. It invites the reader to consider the place and value of human skills in the creative process more generally. In writing about the implications of replacing drawing by hand with computer-assisted design in architectural work, Sennett addresses what gets lost mentally with screen work: "As in other visual practices, architectural sketches are often pictures of possibility; in the process of crystallizing and refining them by hand, the designer proceeds just as a tennis player or musician does, gets deeply involved in it, matures thinking about it" (40). To an architect, Sennett writes, the very activity of drawing by hand prompts thoughts about materiality and an engagement with solidity (41). The sociologist warns against thinking about craftsmanship as anything else than ethically ambiguous, however, and points out that Robert Oppenheimer was a "committed craftsman" (11).

9 Are these observations relevant for how we can conceive of the handwritteness of comics, and for how we can regard the work of an auteur such as Sacco? It would be naive, of course, to think that a hand-drawn depiction of Rudy Kelly is ethically superior to a photographic record. Nevertheless, I would argue that Sacco's method in Days of Destruction, Days of Revolt-to render its subjects by hand-defines the book's commitment to their stories. As I have argued elsewhere, Sacco's approach of drawing oral testimony enables an ethical act of the imagination that involves the triangular constellation of the subject, the artist, and the reader ("The Unmaking of the World" 60). The nature of this engagement will vary from story to story. In the case of Kelly, the texture and the style of Sacco's expression represents a form of commentary in its own right. Kelly's description of how he felt joy in hard 
manual labor in the mines in the years before they were mechanized (135) is rendered roughly and unsentimentally, in a black and white that brings association to carving and scratching, to etchings and prints. Much of the chapter from West Virginia describes how coal is excavated in the state today, with the method known as "mountaintop removal." A "dragline" excavator costs around a hundred million dollars and can be twenty stories tall; it can do the work of hundreds of miners (128). Kelly's story, drawn with great care by hand, is thus haunted by what Sennett in The Culture of the New Capitalism calls "the specter of uselessness" (83), at the same time as it is an expression of a way in which a human being can render interhuman relationships by making use of his hands.

10 ur first visual encounter with Kelly, a portrait of him sitting in his living room chair, illustrates this dimension of Sacco's depiction well (Figure 1).

Figure 1

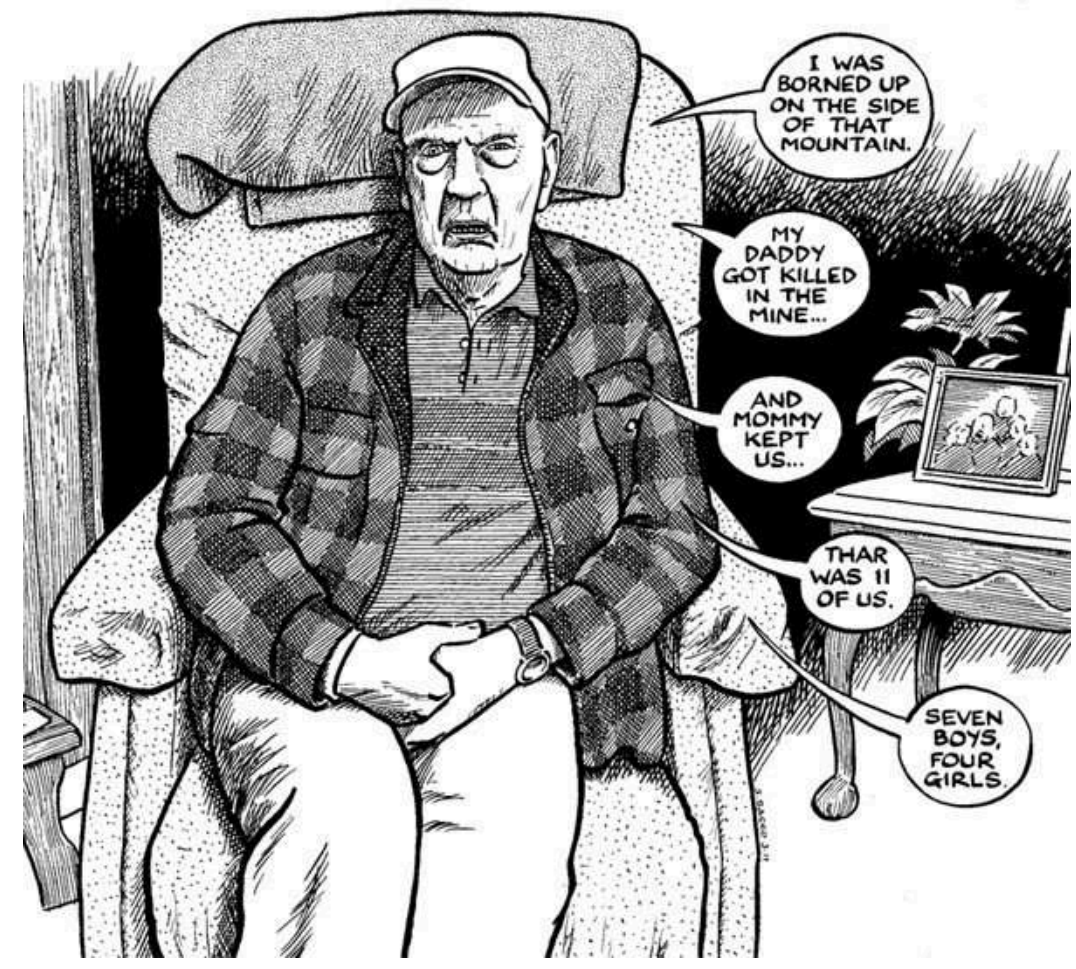

11 The drawing admits its artifice by visualizing Kelly's words in speech balloons, portraying him, in effect, as a comics character, preparing the reader for the narrative that will follow. Kelly is addressing us, as is the case with almost all the individuals portrayed in the book. Two distinct features stand out: his gaze and the hands folded in his lap. As Scherr observes, Sacco's attention to hands in much of his work suggests that it is a recurrent, many-layered motif (22-23). Kelly's hands are in a sense the repository of his working life; in the narrative that follows we see him carrying bags of ice and shoveling coal, and finally, in the last panel, solemnly bowing forward while placing his left hand in that of a minister who has joined him to pray: his life story is framed by gestures of finality. His gaze is marked by a sharp intensity; his left eye squints, giving his 
right eye a heightened confrontational quality. This feature is used to full effect as Sacco depicts him in-narration in several panels as his story unfolds. The mode of address is such that the reader never forgets that these are Kelly's words. When he addresses the reader directly, his transcribed speech appears in balloons; when it appears in the captions, it is quoted ad verbatim in quotation marks, an effect that resembles the use of voice-over in documentary film. Whenever Sacco makes additions or changes to the transcript, he signals this to the reader with scholarly precision, making use of brackets, capital letters and elliptical constructions to show where he has made any editorial changes. The authors have attempted to capture the oral quality of the transcript in order to present the narrative with authenticity; Kelly's voice is thus marked by a vernacular quality. The fact that his speech is lettered by hand is also of significance. The editing does not only reflect the careful selection of passages of speech from extensive transcripts of conversation, but also particular challenges that come from the economy of the expression. Drawing and hand-lettering are skills, but so is the capacity to take care in telling another human being's story so that it is true to his own experience of it.

12Several of the illustrations in Days of Destruction, Days of Revolt are of landscapes. A couple of pages before the encounter with Kelly there is a fullpage drawing of the remnants of the Alpheus Preparation Plant, once the largest coal-cleaning facility in the world (131). The image is characteristic of many of the landscapes in the book: no human being can be seen, only the desolate structures of a facility in decay. Landscape scenes from the small town of Jenkinjones follow Kelly's story; they resemble nothing as much as Sacco's work from a war-torn Bosnia. Decrepit buildings are crumbling along the empty main road of what used to be a bustling coal town (144-147). The activity is elsewhere, the reader understands, from a double page-illustration of an aerial view of the destructive effects of mountaintop removal (126-127). Along with Hedges, Sacco joins chemistry professor and pilot Susan Lapis on a helicopter ride over the coalfields. The huge and heavy machinery on the ground looks like miniature, adding a sense of the enormity of the proportions at play in such large-scale industrial activity; the authors and the reader are given a guided tour of immense pollution and comprehensive destruction of the natural resources in the area. We are introduced to the aerial view of the fields, then to the desolate streets, then to Rudy Kelly in his living room chair and to his memories, and it is as if we are zooming in on an individual that it was impossible to see in the early pages.

$13^{\prime \prime}$ It is awfully hard to photograph a human right," Susie Linfield observes in The Cruel Radiance: "what in the world would it look like?" Photographs are an ideal medium, she argues, because they can show us the absence of human rights, and what that absence "does to a person" (37). The same argument can be made for the photographic depiction of poverty, of unemployment, of certain illnesses. As Rebecca Scherr points out, photographs and drawings might both be visual expressions able to document human rights abuses, but in different ways, and the comics format has the critical potential to "intervene" within what she with reference to Wendy Hesford calls "the affective economy" 
(26). Whether one believes in the widely repeated argument that photographs desensitize the viewer, as theorists such as Susan Sontag and Frederic Jameson have argued, or not, there is little doubt that the drawn images in Days of Destruction, Days of Revolt, appearing in the context of social reportage, will have the capacity to represent its subjects less formulaically than most photographs do. It is hard to see what kind of photographic style that would improve on the rendering of an individual such as Rudy Kelly.

14In writing about the photographic essay as a form of mixed medium, W.J.T. Mitchell proposes the term "imagetext" to describe how it is structured to involve a dynamic verbal-visual relation; "texts explain, narrate, describe, label, speak for (or to) the photographs; photographs illustrate, exemplify, clarify, ground, and document the text" (Mitchell 1994: 94). Instead of simply separating image and word and analyzing one or the other, or stating the difference between them, Mitchell insists that the question to ask of such image-text relations is: "why does it matter how words and images are juxtaposed, blended, or separated?" (91). Let Us Now Praise Famous Men opened with a portfolio of pictures by Evans before Agee's writing and separated the two elements into two distinct parts instead of integrating word and image throughout its pages. Vollmann's book is structured the other way around; it consists of a series of chapters that culminate in an extensive portfolio of 128 of his own photographs of his subjects around the world, which are sectioned loosely according to the chapters that precede them. As Mitchell and Greil Marcus both observe there are good reasons that the composition of Let Us Now Praise Famous Men have been widely read as statement that the text has more substance than the pictures. Of course, the text can go into a different sort of depth and detail, Marcus says in an interview, but then asks: "Which has entered American consciousness? Obviously the images, which have travelled, have penetrated, in a way that the book never has" (Grønstad and Vågnes). Readers can also sense this internal competition between elements in Poor People, which by putting all the pictures in the back of the book seems to suggest that they would interfere with the reading if they appeared in the chapters.

15In Hedges and Sacco's account, words and images bleed into each other, and the book's "handwritteness," I would argue, contributes to this, to giving an organic air to the book's medial mix. One is reminded of Sacco's New Journalist heroes, and especially Ralph Steadman's drawings in Hunter Thompson's work, when reading Days of Destruction, Days of Revolt-not because Sacco's approach or style is reminiscent of Steadman's at all, but because their images in their own right are markedly subjective in a way that adds to the work's identity as a distinct form of cultural commentary. Having read Days of Destruction, Days of Revolt it is hard to imagine what the book would have looked like with photographs instead of drawings. This is a testament to its political impact, to its unblinking, confrontational vision-captured nowhere better than in Rudy Kelly's eyes. 


\section{BIBLIOGRAPHY}

Agee, James, and Walker Evans. Let Us Now Praise Famous Men. Boston: Houghton Mifflin, 1960. Print.

Chute, Hillary. “Comics Form and Narrating Lives.” Profession (2011): 107-117. Print.

Grønstad, Asbjørn, and Øyvind Vågnes. "Interview with Greil Marcus and Werner Sollors.” Journal of American Studies 45 (2011): 5-29. Print.

Hallas, Roger. "Photojournalism, NGOs, and the New Media Ecology." Sensible Politics: The Visual Culture of Nongovernmental Activism. Ed. Meg McLagan and Yates McKee. New York: Zone Books, 2012. 95-114. Print.

Harcourt, Bernard E. "Political Disobedience." Critical Inquiry 39.1 (2012): 33-55. Print.

Hardesty, Michele. "Looking for the Good Fight: William T. Vollmann's An Afghanistan Picture Show." boundary 2 36. 2 (2009): 99-124. Print.

Hatfield, Charles. Alternative Comics: An Emerging Literature. Jackson: University of Mississippi Press, 2005. Print.

Linfield, Susie. The Cruel Radiance: Photography and Political Violence. Chicago: University of Chicago, 2010. Print.

Massey, Douglas S. Categorically Unequal: The American Stratification System. New York: Russel Sage Foundation, 2008. Print.

Mitchell, W.J.T. Picture Theory: Essays on Verbal and Visual Representation. Chicago: University of Chicago Press, 1994. Print.

Murolo, Priscilla, and A. B. Chitty. From the Folks Who Brought You the Weekend: A Short, Illustrated History of Labor in the United States. New York: The New Press, 2001. Print.

Vollmann, William T. Poor People. New York: Harper Perennial, 2007. Print.

Ward, Paul. Documentary: The Margins of Reality. London and New York: Wallflower, 2005. Print.

Sacco, Joe. Journalism. New York: Metropolitan Books, 2012. Print.

Sacco, Joe, and Chris Hedges. Days of Destruction, Days of Revolt. New York: Nation Books, 2012. Print.

Scherr, Rebecca. 2013. “Shaking Hands with Other People's Pain: Joe Sacco's Palestine." Mosaic 46.7 (2013): 19-36. Print.

Sennett, Richard. The Craftsman. New Haven and London: Yale University Press, 2008. Print.

---. The Culture of the New Capitalism. New Haven and London: Yale University Press, 2006. Print.

Spurgeon, Tom. Interview with Joe Sacco. The Comics Reporter. 11 Jan 2013. 5 Jun 2013. Web.

http://www.comicsreporter.com/index.php/cr_holiday_interview_23_joe_sacco/

Vågnes, Øyvind. "The Unmaking of the World: Trauma and Testimony in Two Stories by Joe Sacco." Afterimage 39.1/2 (2011): 60-63. Print.

---. "Inside the Story: A Conversation with Joe Sacco." Journal of Graphic Novels and Comics 1.2 (2010): 193-216. Print. 


\section{ABSTRACTS}

At first sight Chris Hedges and Joe Sacco's Days of Destruction, Days of Revolt belongs solidly in the same tradition as books such as James Agee and Walker Evans's classic Let Us Now Praise Famous Men (1941), which grew out of an assignment in 1936 to produce a magazine article on the conditions sharecropper families in the South lived under during the "Dust Bowl," as well as William T. Vollmann's 2007 book Poor People.Days of Destruction, Days of Revolt describes the predicament of the rapidly growing underclass in the States, victims of corporate capitalism in what Hedges refers to as "sacrifice zones," areas that have been offered up for exploitation in the name of profit. The reader is introduced to despaired people living on the Pine Ridge Lakota reservation in South Dakota; the homeless of Camden, N.J.; migrant workers assigned to pick tomatoes in worker camps in Florida; and individuals suffering from and resisting mountain-top removal by coal companies in West Virginia. However, Days of Destruction, Days of Revolt departs from this tradition of social reportage in several significant ways, and my article will address how-with a particular focus on the book's use of drawingsand comics reportage in the place of photography. What are the implications of this particular verbal-visual strategy? Interrogating the ethics of the drawn documentary image inevitably implies addressing its peculiar, somewhat paradoxical authenticity, and to think of how drawings differ from photographs in how they depict the world. In my discussion of this I'll draw on both documentary and comics theory (Paul Ward, Hillary Chute, Charles Hatfield). I will argue that the use of drawn images in Days of Destruction, Days of Revolt results in a new form of what W.J.T. Mitchell calls "imagetext," one that raises its fundamental social and political questions with energy, passion, and ethical integrity.

\section{INDEX}

Mots-clés: Chris Hedges, Days of Destruction, Days of Revolt, Hillary Chute, James Agee, Joe Sacco, Let Us Now Praise Famous Men, Poor People, Richard Sennett, The Craftsman, Walker Evans, William T. Vollmann

Keywords: comics, documentary, photography, social reportage

\section{AUTHOR}

\section{ØYVIND VÅGNES}

Independent Scholar 